\title{
ANALISIS KESULITAN BELAJAR STATISTIKA MAHASISWA PENDIDIKAN TATA BOGA
}

\author{
Win Berkat Nurdianto, Ade Juwaedah' ${ }^{1}$, Karpin ${ }^{2}$ \\ Program Studi Pendidikan Tata Boga, Departemen Pendidikan Kesejahteraan \\ Keluarga, Fakultas Pendidikan Teknologi dan Kejuruan, Universitas Pendiidkan \\ Indonesia
}

winberkatnurdianto@gmail.com

\begin{abstract}
Abstrak: Kesulitan belajar merupakan gejala dimana individu tidak bisa belajar sebagaimana mestinya, hal ini bisa disebabkan oleh materi pembelajaran yang sulit serta faktor internal dan eksternal individu itu sendiri. Kesulitan belajar ini diduga dialami oleh mahasiswa Program Studi Pendidikan Tata Boga pada mata kuliah statistika. Penelitian ini bertujuan untuk mengetahui materi mengenai pengertian istilah dasar statistika dan materi statistika dalam bentuk kasus yang dianggap sulit serta faktor internal penyebab kesulitan belajar statistika. Penelitian ini menggunakan metode deskriptif kuantitatif. Populasi penelitian adalah mahasiswa Prodi Pendidikan Tata Boga angkatan tahun 2017 dengan jumlah 44 orang. Dari hasil penelitian ditemukan bahwa pada materi pengertian istilah dasar statistika mahasiswa Prodi Pendidikan Tata Boga angkatan 2017 mengalami kesulitan belajar dengan kategori sangat sulit yaitu pada materi analisis regresi dan kurtosis, dan kategori sulit yaitu pada materi ukuran kemiringan, hipotesis dan analisis korelasi. Pada materi bentuk kasus mengalami kesulitan belajar dengan kategori sangat sulit pada materi ukuran kemiringan, kurtosis dan analisis regresi, pada materi dengan kategori sulit yaitu ukuran dispersi, hipotesis dan analisis korelasi, sedangkan kategori materi cukup sulit yaitu pada materi penyajian data dan ukuran letak. Faktor internal yang menyebabkan kesulitan belajar dengan kategori besar penyebabnya yaitu kebiasaan belajar, dan faktor internal penyebab kesulitan belajar dengan kategori cukup besar adalah minat belajar, motivasi belajar dan kemampuan belajar. Mahasiswa mengalami kesulitan belajar pada materi statistika pengertian dasar dan materi bentuk kasus dimana disebabkan empat faktor internal. Rekomendasi dari hasil penelitian ini yaitu memperbaiki intensitas dan cara belajar dengan memperbaiki aspek internal untuk memaksimalkan pemahaman serta hasil belajar statistika.
\end{abstract}

Kata Kunci: Faktor internal, Kesulitan belajar statistika.

\section{PENDAHULUAN}

Kesulitan belajar merupakan kekurangan yang tidak nampak secara lahiriah. Ketidak mampuan dalam belajar tidak dapat dikenali dalam wujud fisik yang berbeda dengan orang yang tidak mengalami masalah kesulitan belajar.

Kesulitan belajar ini diduga dialami oleh mahasiswa Pendidikan Tata Boga pada mata kuliah statistika. Berdasarkan data dari dosen pengampu mata kuliah statistika mahasiswa Pendidikan Tata Boga pada angkatan 2016, terdapat 36 dari 61 mahasiswa yang memiliki nilai $\mathrm{C}$ dengan kata lain setengah dari jumlah mahasiswa dikelas mendapatkan nilai yang tidak optimal. Peneliti menduga kesulitan ini juga dialami oleh mahasiswa Pendidikan Tata Boga pada angkatan 2017 yang telah mengontrak mata kuliah statistika.

Penelitian ini memfokuskan untuk mencari fakta mengenai materi pengertian dasar dan materi statistika dalam bentuk kasus yang dianggap sulit, dan hanya sampai pada meneliti faktor internal yang menyebabkan kesulitan belajar. 


\section{METODE}

Penelitian ini menggunakan metode deskriptif kuantitatif dengan instrumen berbentuk kuesioner tertutup. Dengan skala penilaian yang digunakan adalah skala Guttman dan skala Likert. Skala Guttmn digunakan untuk kuesioner pengetahuan dasar statistika, dan skala Likert untuk materi bentuk kasus dan faktor internal penyebab kesulitan belajar.

Responden yang dilibatkan dalam penelitian ini adalah seluruh mahasiswa Pendidikan Tata Boga angkatan tahun2017 yang telah mengontrak mata kuliah statistika dengan jumlah populasi 44 orang.

Riduwan, 2012, hlm. 87 mengemukakan bahwa kriteria interpretasi skor berkaitan dengan penelitian ini, ialah sebagai berikut :

- Kriteria pengetahuan Dasar dan Materi Bentuk Kasus

$$
\begin{aligned}
81,0 \%-100 \% & =\text { Sangat sulit } \\
61,0 \%-80,9 \% & =\text { Sulit } \\
41,0 \%-60,9 \% & =\text { Cukup Sulit } \\
21,0 \%-40,9 \% & =\text { Mudah } \\
0 \%-20,9 \% & =\text { Sangat Mudah }
\end{aligned}
$$

- Kriteria Faktor Internal Penyebab Kesulitan belajar

$$
\begin{aligned}
81,0 \%-100 \% & =\text { Sangat Kecil } \\
61,0 \%-80,9 \% & =\text { Kecil } \\
41,0 \%-60,9 \% & =\text { Cukup Besar } \\
21,0 \%-40,9 \% & =\text { Besar } \\
0 \%-20,9 \% & =\text { Sangat Besar }
\end{aligned}
$$

\section{HASIL DAN PEMBAHASAN}

Kesulitan belajar ini dialami oleh mahasiswa pendidikan tata boga angkatan 2017 pada matakuliah statistika, yang terdiri dari materi pokok pengertian dasar dan materi statistika dalam bentuk kasus dan faktor internal penyebab kesulitan belajar.

Pada gambar tabel 4.1 menunjukan mahasiswa mengalami kesulitan belajar pada beberapa materi pokok pengertian dasar statistika dimana terletak pada kriteria sulit dan sangat

\begin{tabular}{|c|c|c|c|}
\hline No & $\begin{array}{c}\text { Materi } \\
\text { Pengertian } \\
\text { Dasar } \\
\text { Dalam } \\
\text { Statistika }\end{array}$ & Kriteria & $\begin{array}{c}\text { Persentase } \\
(\%)\end{array}$ \\
\hline 1. & $\begin{array}{c}\text { Pengertian } \\
\text { Dasar Dalam } \\
\text { Statistika }\end{array}$ & Mudah & 24,5 \\
\hline 2. & $\begin{array}{c}\text { Penyajian } \\
\text { Data }\end{array}$ & Mudah & 34,1 \\
\hline 3. & $\begin{array}{c}\text { Ukuran } \\
\text { Pemusatan }\end{array}$ & $\begin{array}{l}\text { Sangat } \\
\text { Mudah }\end{array}$ & 12,9 \\
\hline 4. & $\begin{array}{l}\text { Ukuran } \\
\text { Letak }\end{array}$ & Mudah & 38,6 \\
\hline 5. & $\begin{array}{c}\text { Ukuran } \\
\text { Kemiringan }\end{array}$ & Sulit & 65,9 \\
\hline 6. & Kurtosis & $\begin{array}{c}\text { Sangat } \\
\text { Sulit }\end{array}$ & 81,8 \\
\hline 7. & Hipotesis & Sulit & 65,1 \\
\hline 8. & $\begin{array}{l}\text { Analisis } \\
\text { Regresi }\end{array}$ & $\begin{array}{c}\text { Sangat } \\
\text { Sulit }\end{array}$ & 88,6 \\
\hline 9. & $\begin{array}{l}\text { Analisis } \\
\text { Korelasi }\end{array}$ & Sulit & 79,5 \\
\hline
\end{tabular}
sulit, menurut Derek Wood (2012, hal 26-29) kesulitan belajar dibagi menjadi tiga kategori besar yaitu: 1) Kesulitan memusatkan perhatian, 2) Lupa dalam belajar, 3) Peristiwa jenuh dalam belajar.

Tabel 4.1

Kesulitan Belajar Materi Pokok

Pengertian Istilah dalam Statistika

Berdasarkan tabel 4.1 kriteria sulit terletak pada materi ukuran kemiringan, hipotesis, dan analisis korelasi, menurut Derek Wood (2012, hal.26) kategori kesulitan belajar ini salah satunya dikarenakan lupa, dimana hal itu bisa disebabkan lamanya tenggang waktu antara saat terjadinya proses belajar sebuah materi dengan saat pengungkapannya. Kriteria sangat sulit terletak pada materi kurtosis dan analisis regresi dan bisa terjadi karena kejenuhan, menurut menurut Derek Wood (2012, hal 29) 
kategori kesulitan belajar salah satunya dikarenakan kejenuhan belajar, yaitu rentang waktu yang digunakan untuk belajar tetapi tidak mendapatkan hasil.

Pada tabel 4.2 mahasiswa mengalami kesulitan belajar pada materi statistika bentuk kasus, dimana kesulitannya terletak pada kriteria cukup sulit, sulit dan sangat sulit. Pada materi bentuk kasus, menurut Wena (2011, hal.52) dalam materi bentuk kasus dilakukan operasi prosedural urutan tindakan, tahap demi tahap secara sistematis, sebagai seorang pemula memecahkan masalah. Mengacu pada prosedural sistematis maka digunakan solusi pemecahan masalah menurut Polya (1973, hal.6) dimana kita harus memahami masalah, selanjutnya merencanakan penyelesaian, kemudian menyelesaikan masalah sesuai rencana yang dianggap tepat, dan langkah terakhir melakukan pengecekan kembali jawaban yang sesuai dengan permasalahan.

Kemudian pengkategorian kesulitan dibagi menjadi 4 macam, yaitu tidak memahami konsep, sulit merencanakan perencaan, sulit melakukan perencanaa, dan sulit melakukan evaluasi.

Tabel 4.2

Kesulitan dalam Memahami Materi

\begin{tabular}{cccc}
\multicolumn{3}{c}{ Pokok Statistika Bentuk Kasus } \\
\hline No & $\begin{array}{c}\text { Materi } \\
\text { Statistika } \\
\text { Bentuk } \\
\text { Kasus }\end{array}$ & Kriteria & $\begin{array}{c}\text { Persentase } \\
(\%)\end{array}$ \\
\hline 1. & $\begin{array}{c}\text { Penyajian } \\
\text { Data }\end{array}$ & $\begin{array}{c}\text { Cukup } \\
\text { Sulit }\end{array}$ & 50,56 \\
2. & $\begin{array}{c}\text { Ukuran } \\
\text { Pemusatan }\end{array}$ & Mudah & 30,2 \\
3. & $\begin{array}{c}\text { Ukuran } \\
\text { Letak }\end{array}$ & $\begin{array}{c}\text { Cukup } \\
\text { Sulit }\end{array}$ & 55,7 \\
\hline 4. & $\begin{array}{c}\text { Ukuran } \\
\text { Dispersi }\end{array}$ & Sulit & 69,2 \\
5. & Ukuran & Sangat & 87,7 \\
\hline
\end{tabular}

\begin{tabular}{|c|c|c|c|}
\hline & Kemiringan & Sulit & \\
\hline 6. & Kurtosis & $\begin{array}{c}\text { Sangat } \\
\text { Sulit }\end{array}$ & 90,4 \\
\hline 7. & Hipotesis & Sulit & 78,6 \\
\hline 8. & $\begin{array}{l}\text { Analisis } \\
\text { Regresi }\end{array}$ & $\begin{array}{c}\text { Sangat } \\
\text { Sulit }\end{array}$ & 84,3 \\
\hline 9. & $\begin{array}{l}\text { Analisis } \\
\text { Korelasi }\end{array}$ & Sulit & 71,6 \\
\hline
\end{tabular}

Berdasarkan data Tabel 4.2 kriteria cukup sulit terletak pada materi penyajian data dan ukuran letak, kriteria cukup sulit menurut Polya (Suherman, 2001, hal 84) adalah sulit melaksanakan rencana penyelesaian masalah, dimana mahasiswa mengetahui rumus tapi tidak bisa mengerjakan rumus tersebut.

Kriteria sulit terletak pada materi ukuran dispersi, hipotesis dan analisis korelasi, kriteria sulit menurut Polya (Suherman, 2001, hal 84) adalah sulit membuat rencana untuk memecahkan masalah, dimana mahasiswa tidak mengetahui rumus apa yang harus digunakan untuk menyelesaikan materi bentuk kasus.

Kriteria sangat sulit terletak pada materi ukuran kemiringan, kurtosis, dan analisis regresi, kriteria sangat sulit menurut Polya (Suherman, 2001, hal 84) adalah terletak pada ketidak pahaman terhadap konsep masalah.

Pada tabel 4.3 faktor internal penyebab kesulitan belajar dengan kriteria cukup besar dan besar, faktor internal penyebab kesulitan belajar terdiri dari minat belajar, motivasi belajar, kemampuan belajar dan kebiasaan belajar. 
Tabel 4.3

Faktor Internal Penyebab Kesulitan Belajar

\begin{tabular}{cccc}
\hline No & $\begin{array}{c}\text { Aspek } \\
\text { Internal }\end{array}$ & Kriteria & $\begin{array}{c}\text { Persentase } \\
(\mathbf{\%})\end{array}$ \\
\hline 1. & Minat & Cukup & 60,6 \\
& Belajar & Besar & \\
2. & $\begin{array}{c}\text { Motivasi } \\
\text { Belajar }\end{array}$ & $\begin{array}{c}\text { Cukup } \\
\text { Besar }\end{array}$ & 59,6 \\
3. & $\begin{array}{c}\text { Kemampuan } \\
\text { Belajar }\end{array}$ & $\begin{array}{c}\text { Cukup } \\
\text { Besar }\end{array}$ & 57 \\
4. & $\begin{array}{c}\text { Kebiasan } \\
\text { Belajar }\end{array}$ & Besar & 38,4 \\
\hline
\end{tabular}

Berdasarkan data Tabel 4.3 kriteria faktor penyebab kesulitan belajar yang cukup besar adalah minat belajar, motivasi belajar, kemampuan belajar, menurut Aunurahman (2014, hal.195), bahwa minat belajar yang kurang baik, kurangnya motivasi dalam belajar, kurangnya kemampuan belajar akan membuat mahasiswa cenderung tidak memperhatikan pembelajaran. dan faktor internal penyebab kesulitan yang besar adalah kebiasaan belajar, menurut Aunurahman (2014, hal.196), bahwa kebiasaan belajar yang tidak baik akan menjadi kebiasaan buruk yang membuat mahasiswa kesulitan dalam belajar.

\section{KESIMPULAN}

Berdasarkan hasil pembahasan penelitian disimpulkan bahwa:

Mahasiswa Pendidikan Tata Boga angkatan 2017 mengalami kesulitan belajar pada pengertian istilah dasar dalam materi statistika. Kesulitan belajar terjadi pada beberapa sub materi diantaranya ukuran kemiringan, kurtosis, hipotesis, analisis korelasi dan yang dianggap paling sulit adalah sub materi analisis regresi.

Mahasiswa Pendidikan Tata Boga angkatan 2017 mengalami kesulitan belajar pada materi statistika dalam bentuk kasus. Kesulitan belajar pada materi statistika bentuk kasus dibagi menjadi tiga kategori, pertama kategori cukup sulit pada sub materi penyajian data, ukuran letak, kedua kategori sulit pada sub materi dispersi, hipotesis, analisis korelasi, ketiga kategori sangat sulit pada sub materi ukuran kemiringan, kurtosis, dan analisis regresi.

Berdasarkan hasil penelitian, faktor internal yang terdiri dari minat belajar, motivasi belajar dan kemampuan belajar merupakan faktor penyebab kesulitan belajar yang cukup besar yang dialami mahasiswa dalam belajar statistika, dan kebiasaan belajar adalah faktor penyebab kesulitan belajar yang besar yang dialami mahasiswa dalam belajar statistika.

\section{REFERENSI}

Aunurrahman. (2010). Belajar dan Pembelajaran. Bandung: Alfabeta

Derek Wood. (2012). Kiat Mengatasi Gangguan Belajar. Jogjakarta: Ar-Ruzz Media

Polya, George. 1973. How TO Solve It:A New Aspect Of Mathematical Method. New Jersey. Universiti Press

Suherman, Erman.(2001). Startegi Pembelajaran Matematika Kontemporer. Bandung. JICA UPI

Wena, Made. (2011). Startegi Pembelajaran Inovatif Kontemporer: Suatu Tinjauan Konseptual Operasional.Jakarta: Bumi Aksara 